\title{
KINERJA GURU KELAS DI TENGAH PANDEMI COVID-19 PADA MATERI IPS KELAS 5 SDN LARANGAN LUAR 03 PAMEKASAN
}

\author{
Ahmad Imam Khairi ${ }^{1}$, Moh. Imam Sufiyanto ${ }^{2}$ \\ 1,2Institut Agama Islam Negeri Madura \\ khairi.ahmadimam@gmail.com, bersamabiologi@gmail.com
}

\begin{abstract}
ABSTRAK
Pendidikan di Indonesia saat ini mengalami perubahan dalam proses kegiatan belajar mengajar, hal ini terjadi disebabkan oleh wabah atau pandemic covid-19 yang melanda dunia maupun Indonesia belum berakhir. Dari proses belajar tatap muka secara langsung di sekolah, sekarang proses pembelajaran dilakasanakan secara online dari rumah masing-masing dengan memanfaatkan teknologi. Tujuan penelitian ini adalah untuk mengetahui kinerja guru ditengah pandemic covid-19 pada Sekolah Dasar Negeri Larangan Luar 03 Pamekasan yang dilakukan secara online. Metode Penelitian yang digunakan adalah studi kasus ekslorasi berupa deskriptif kualititatif yaitu kegiatan untuk mendapatkan data penelitian yang bersifat apa adanya dengan kondisi tertentu dimana hasilnya lebih menekankan terhadap makna yang didapat dengan menggunakan google form yang dikirim kepada guru. Hasil penelitian didapat bahwa rata-rata dari Guru kelas yang bertugas mengajar pada kelas lima SDN Larangan Luar 03 Pamekasan yang melaksanakan kegiatan pembelajaran secara online atau daring adalah sebesar $67 \%$, sisanya $33 \%$ persen melaksanakan kegiatan pembelajaran secara Blended Learning. kemudian didapat pula bahwa $100 \%$ dari guru tersebut merencanakan pembelajaran sebelum pembelajaran daring dilaksanakan dengan membuat perangkat pembelajaran yang disesuaikan. Kesimpulan yang didapat yakni para guru bekerja keras untuk tetap menyampaikan pembelajaran kepada siswasiswinya agar proses kegiatan belajar mengajar tetap terlaksana dengan baik, meskipun terdapat beberapa faktor penghambat dalam pelaksanaan pembelajaran yang ditemui, mulai dari masih banyaknya siswa yang belum mempunyai handphone, kendala akses jaringan sampai pada kuota internet.
\end{abstract}

Kata kunci: Kinerja Guru; Pandemi Covid-19; Pembelajaran Daring 


\begin{abstract}
Education in Indonesia is currently experiencing changes in the teaching process activities. This is happening because the COVID-19 outbreak or pandemic that has hit the world and Indonesia has not ended. From the face-to-face learning process directly at school, now the learning process is carried out online from their respective homes by utilizing technology. The purpose of this study was to determine the performance of teachers in the midst of the covid-19 pandemic at the SDN Larangan Luar 03 Pamekasan, which was carried out online. The research method used is an exploratory case study in the form of qualitative descriptive, which is an activity to obtain data that is as it is under certain conditions, whose results emphasize the meaning obtained by using the Google form sent to the teacher. The results showed that the average of the class teachers in charge of teaching in fifth grade at SDN Larangan Luar 03 Pamekasan who carried out online or online learning activities was 67\%. The remaining 33\% carried out blended learning activities. Then it was also found that $100 \%$ of the teachers planned learning before online learning was carried out by making customized learning tools. The conclusion obtained is that teachers work hard to continue to convey learning to their students so that the teaching and learning process continues to run well, although there are several inhibiting factors in the implementation of learning that are encountered, ranging from the number of students who do not have mobile phones to network access constraints. until the internet quota.
\end{abstract}

Keywords: Teacher Performance; pandemic covid-19; Online Learning

\title{
PENDAHULUAN
}

Situasi pandemi global saat ini, WHO (World Health Organization) telah mengumumkan bahwa pandemi Covid-19 telah melanda seluruh dunia, pemerintah dalam hal ini Presiden Joko Widodo dalam pidatonya mengintruksikan untuk masyarakat Indonesia untuk mengurangi mobilitas maupun kegiatan di luar rumah untuk kegiatan yang tidak penting. Termasuk menerapkan sistem kerja Work From Home (WFH) Digunakan untuk kegiatan belajar di sekolah dan konferensi online (online). Ini merupakan langkah strategis yang diambil pemerintah untuk mencegah wabah virus corona saat ini di Indonesia, apalagi dengan berkembangnya varian baru.

Menteri Pendidikan Indonesia Nadiem Makariem mengajak guru dan dosen juga melakukan Work From Home atau bekerja dari rumah. Menteri Nadiem menyampaikan kegiatan mengajar bisa dilakukan dari rumah menggunakan dan pemanfaatan teknologi. Guru dan dosen di wilayah terdampak Covid-19 sebaiknya tidak pergi ke sekolah atau kampus. Imbauan kepada guru dan dosen ini disampaikan Mendikbud Nadiem terkait penghentian sementara aktivitas 
pembelajaran tatap muka di sekolah maupun perguruan tinggi di daerah terdampak virus corona atau Covid-19. Para pendidik dan tenaga kependidikan juga diimbau tidak perlu datang ke sekolah ataupun kampus.

Pendidikan pada dasarnya adalah usaha sadar untuk mengembangkan potensi sumber daya manusia peserta didik dengan cara mendorong dan menggalakkan kegiatan belajar peserta didik. Pendidikan merupakan salah satu pilar utama yang menentukan perubahan sosial. Menuju kemajuan dan perubahan kualitas hidup sejahtera. Sebagaimana tercantum dalam garis besar kebijakan nasional, proses pendidikan bertanggung jawab untuk mewujudkan generasi bangsa yang utuh, yaitu mewujudkan masyarakat Indonesia yang damai, demokratis, adil, kompetitif, maju, dan sejahtera dalam kerangka Indonesia. Negara Kesatuan Republik Indonesia yang didukung oleh masyarakat yang sehat, mandiri, dan mandiri. Memiliki iman, takwa, akhlak mulia, cinta tanah air, memahami hukum dan lingkungan, menguasai ilmu pengetahuan dan teknologi, memiliki derajat etika dan disiplin kerja yang tinggi. ${ }^{1}$

Guru sendiri adalah tenaga profesional yang mengemban tugas mengajar, pendidikan dan pelatihan. Pendidikan berarti melanjutkan dan mengembangkan nilai-nilai kehidupan. Mengajar berarti melanjutkan dan mengembangkan ilmu pengetahuan dan teknologi. Meskipun pelatihan berarti mampu mengembangkan keterampilan siswa. ${ }^{2}$

Supaya pelaksanaan pendidikan dapat terlaksana dengan baik, guru dituntut untuk memiliki kinerja yang baik pula. Namun Memasuki tahun 2020, dunia sedang dilanda wabah, pandemi Covid-19. Pandemi COVID-19 merupakan krisis kesehatan yang telah menyebar hampir ke seluruh penjuru dunia. Pandemi telah mempengaruhi beberapa bidang, salah satunya adalah sektor pendidikan. Banyak negara telah memutuskan untuk menutup sementara sekolah dan kampus selama pandemi COVID-19. Setiap negara memiliki kebijakan untuk mengatasi permasalahan yang sedang terjadi. Untuk mengatasi pandemi Covid-19, seluruh negara telah melakukan tindakan, salah satunya adalah social distancing atau jarak sosial, yang bertujuan untuk mengurangi 4.444 interaksi di antara 4.444 orang di seluruh masyarakat. Akibat keterasingan sosial, pembelajaran di sekolah menjadi terhambat dan tidak dapat dilaksanakan secara langsung, yang juga berdampak pada terselenggaranya kegiatan Pendidikan. Wujud dari social distancing pada guru adalah dengan kegiatan guru yang dilakasanakan secara Work From Home sehingga Bekerja lebih fleksibel dan tidak mematuhi jam kantor,tanpa Perlu membayar transportasi atau bensin, yang dapat meminimalkan tingkat stres

1 Achmad Patoni, Dinamika Pendidikan Anak (Jakarta: PT. Bina Ilmu, 2004).

2 M. Miftahul Ulum Basuki, Pengantar Ilmu Pendidikan Islam (Ponorogo: STAIN Ponorogo Press, 2007). 
yang dialami Selain kemacetan lalu lintas dari rumah ke tempat kerja, ada lebih banyak waktu luang. Kelemahan dari bekerja dari rumah adalah kehilangan motivasi untuk membayar listrik dan Internet, yang dapat menyebabkan masalah keamanan data. ${ }^{3}$.

Permasalahan pada sistem pembelajaran online yang pertama adalah lemahnya jaringan internet, hal ini terutama bagi guru dan siswa yang tinggal di pedesaan atau pelosok, tentunya akan sangat sulit untuk mendapatkan akses internet walaupun ini salah satunya. yang paling penting. Faktor-faktor dalam pelaksanaan pembelajaran online. Guru akan mengalami kesenjangan teknologi atau technology stuttering, kemampuan guru dalam menggunakan teknologi tentunya akan mempengaruhi kualitas program belajar mengajar. Dapatkan materi secara online. Keempat, belum semua guru dan siswa siap menggunakan sistem pembelajaran online dengan cepat, termasuk guru menyiapkan materi pembelajaran digital. memimpin, mengarahkan, melatih, mengevaluasi dan mengevaluasi siswanya. Kualitas proses pendidikan dalam hal ini kinerja guru sangat menentukan kualitas hasil pendidikan di Indonesia. Dengan menurunnya kinerja guru maka akan menyebabkan proses pembelajaran yang kurang optimal bagi siswa, sehingga kualitas hasil pendidikan di Indonesia juga akan menurun dan sebaliknya. ${ }^{4}$.

\section{METODE PENELITIAN}

Secara garis besar metode penelitian dapat diartikan sebagai suatu kegiatan ilmiah, dimulai dengan mengidentifikasi topik, mengumpulkan data, dan menganalisis data, dan berkembang melalui tahapan untuk memahami dan memahami topik, gejala, atau masalah tertentu. di masa depan. Creswel ${ }^{5}$ Metode penelitian kualitatif didefinisikan sebagai metode atau eksplorasi untuk menggali dan memahami inti fenomena. Untuk memahami fenomena sentral, para peneliti mewawancarai peserta studi atau peserta mengajukan pertanyaan yang cukup umum dan luas..

Penelitian ini menggunakan metode penelitian kasus eksplorasi dan metode penelitian ini menggunakan metode penelitian kasus kualitatif untuk memperoleh informasi yang akan diteliti.. yang mana Penelitian kualitatif adalah penelitian yang menggunakan lingkungan alam, bertujuan untuk menjelaskan apa yang terjadi, dan dilakukan dengan melibatkan berbagai

3 Agus Purwanto, "Studi Eksplorasi Dampak WFH Terhadap Kinerja Guru," Journal of Education, Psychology and Counseling 2, no. 1 (2020): 92-100.

4 S D Inpres et al., "KINERJA GURU SEKOLAH DASAR DI MASA PANDEMI COVID-19 Studi Di SD Inpres Tateli Kecamatan Mandolang Kabupaten Minahasa," Jurnal Administrasi Publik 7, no. 99 (2021): 1-11.

5 Conny R. Semiawan, Metode Penelitian Kualitatif (Jakarta: Grasindo, 2017). 
metode yang ada. ${ }^{6}$. Peneliti adalah sebagai instrument kunci, pengambilan sampel sumber data dilakukan secara proporsive dan snowball, analisis data bersifat induktif/kualitatif, dan hasil penelitian kualitatif lebih menekankan makna dari generalisasi.

Metode deskriptif itu sendiri adalah suatu metode untuk mempelajari keadaan saat ini dari sekelompok orang, suatu objek, sekumpulan kondisi, suatu sistem pemikiran atau suatu jenis peristiwa, dan bertujuan untuk membuat suatu gambaran, gambaran atau representasi yang sistematis, benar dan akurat dari fakta, karakteristik dan hubungan. Diantara fenomena yang diselidiki ${ }^{7}$. Oleh karena itu, penelitian deskriptif adalah penelitian yang menggambarkan fenomena yang terjadi secara nyata, realistik, realistik, dan kekinian, karena jenis penelitian ini merupakan cara yang sistematis, benar dan akurat untuk menelaah fakta, atribut, dan hubungan. atau dicat. Fenomena yang sedang diselidiki.

Dalam penelitian ini, terdapat responden sebanyak 3 orang guru kelas 5 sekolah dasar negeri yang terdapat di Kota Pamekasan Provinsi Jawa Timur. Untuk tujuan kerahasiaan, responden diberi inisial R1, R2, dan R3. Wawancara semi-terstruktur dilakukan dan daftar pertanyaan disusun untuk wawancara dikembangkan berdasarkan literatur terkait. Responden untuk penelitian ini adalah para guru kelas 5 di SDN Larangan Luar 03 yang merupakan salah satu sekolah dasar negeri yang terdapat di kabupaten Pamekasan.

\section{Tabel 1. Profil Responden}

\begin{tabular}{cccc}
\hline Inisial & Jenis Kelamin & Pendidikan & Status Pegawai \\
\hline R1 & $\mathrm{P}$ & $\mathrm{S} 1$ & PNS \\
\hline R2 & $\mathrm{L}$ & $\mathrm{S} 1$ & PNS \\
\hline R3 & $\mathrm{P}$ & $\mathrm{S} 1$ & PNS \\
\hline
\end{tabular}

Jadi pada penelitian ini dalam pengambilan data peneliti menggunakan google form. Dimana google form yang sudah dibuat dikirimkan kepada responden yang merupakan guru sekolah Dasar Negeri Larangan Luar 03 untuk mengisi google form tersebut apa adanya sesuai dengan apa yang dialami oleh masing-masing guru. Data yang sudah masuk kemudian diolah dan dijadikan hasil dari penelitian ini. 2018).

${ }^{6}$ Johan Setiawan Albi Anggito, Metodologi Penelitian Kualitatif (Jawa Barat: CV Jejak,

Ajat Rukajat, Pendekatan Penelitian Kuantitatif Quantitaive Research Approach (Yogyakarta: Deepublish, 2018). 


\section{HASIL DAN PEMBAHASAN}

Gagasan guru harus dilaksanakan untuk kepentingan siswa dan mendukung terciptanya hubungan yang sebaik-baiknya dalam rangka pemeliharaan, pengembangan, dan penerapan nilai-nilai yang berkaitan dengan agama, budaya, dan ilmu pengetahuan ${ }^{8}$. Guru sendiri dibagi menjadi beberapa diantaranya yaitu guru kelas. Tugas seorang guru kelas adalah mengajar atau mengajar di sekolah atau ruang kelas 9 . setiap guru kelas pasti mempunyai kinerja dalam proses pembelajaran.

Bastian $^{10}$ mengemukakan bahwa kinerja adalah gambaran tingkat pencapaian tugas-tugas yang dilakukan dalam suatu organisasi, dalam rangka upaya mencapai tujuan, sasaran, misi dan visi organisasi. Sedangkan kinerja guru merupakan kata bahasa Indonesia yang berasal dari kata dasar "kerja" yang berarti prestasi, yang juga dapat menunjukkan hasil kerja ${ }^{11}$. Kinerja guru memerlukan suatu sistem manajemen kinerja yang dapat menghubungkan tujuan organisasi (lembaga) dengan tujuan dalam proses pembelajaran untuk mencapai kesepakatan tentang tujuan yang ingin dicapai dan bagaimana mengelola staf dengan cara yang benar untuk mencapai tujuan. Pencapaian kinerja tinggi ini dapat dipengaruhi oleh dua faktor. Faktor pertama adalah kemampuan karyawan itu sendiri, termasuk kemampuan potensial dan kemampuan praktis. Kedua, faktor motivasi yang dibentuk oleh sikap karyawan dalam menghadapi situasi kerja. Kinerja guru sangat penting, kita harus memperhatikan, mengevaluasi dan meningkatkannya, karena guru juga mengemban berbagai tugas profesional dan perbaikannya harus dilakukan oleh pemerintah dan guru itu sendiri.

Kinerja guru Di masa pandemi seperti sekarang ini, guru kewalahan dengan proses pembelajaran online (di Internet). Guru umumnya hanya membutuhkan tatap muka buku dan buku pelajaran, namun di masa pandemi seperti ini, guru seringkali harus membuat video materi pembelajaran untuk mempermudah proses belajar mengajar. Guru atau pendidik juga harus menggunakan teknologi dalam proses pembelajaran, karena pembelajaran jarak jauh berlangsung. Misalnya, gunakan aplikasi virtual Google Classroom, aplikasi Zoom, dan aplikasi Google Meet untuk pembelajaran online.

Situasi saat pandemi membuat para tenaga kependidikan mau tidak mau harus melaksanakan pembelajaran secara daring. Hal ini membuat para pendidik terutama pendidik senior atau berusia lanjut yang kurang memahami tentang

8 Syafruddin Nurdin, Guru Profesional Dan Implementasi Kurikulum (Jakarta: Ciputat Press, 2003). 2010).

9 Muhammad Idris Ahmad Barizi, Menjadi Guru Unggul (Yogjakarta: Ar-Ruzz Media,

10 Bastian, Akuntansi Sektor Publik Di Indonesia (Yogyakarta: BPFE, 2001).

11 Didi Pianda, Kinerja Guru (Jawa Barat: CV Jejak, 2018). 
teknologi atau gagap teknologi harus bersusah payah menyesuaikan diri agar tetap melaksanakan pembelajaran secara daring. Para guru harus meningkatkan kinerjanya pada saat pandemi seperti sekarang. Selain peningkatan kinerja guru, sikap dan motivasi belajar pada siswa juga mempengaruhi berlangsungnya proses pembelajaran. Sikap siswa dan motivasi belajar yang tinggi diharapkan dapat membantu mencapai hasil belajar yang terbaik. Banyak psikolog menjelaskan bahwa sikap dan motivasi belajar yang tinggi berdampak pada intensitas belajar yang tinggi.

Dari jawaban pertanyaan pertama yang didapat dari guru tentang bagaimana proses KBM dimasa pandemi yang telah anda lakukan khususnya pada materi IPS Mendapatkan respon jawaban yang cukup beragam, untuk responden dengan inisial inisial R1 mengemukakan bahwa proses KBM dimasa pandemic Kurang efektif dari segi penyampaian materi dan proses pencapaian tujuan pembelajaran terkadang menghadapi kendala terutama dalam memberikan contoh khususnya etnis dan budaya dalam materi IPS, respon lain disampaikan oleh responden inisial R2 yang Melakukan proses pembelajaran online menggunakan google Form dan group Whatssap dengan semaksimal mungkin supaya peserta didik dapat memahami materi dengan baik khususnya pada materi IPS, kemudian responden 3 dengan inisial R3 menyampaikan Pembelajaran daring cukup lancar, meskipun ada kendala terutama dalam memahamkan materi dalam hal ini materi IPS.

Beranjak ke pertayaan kedua tentang Bagaimana evaluasi belajar siswa di tengah pandemi Covid-19, responden R1 menjabarkan bahwa Evaluasi belajar siswa dilakukan secara daring dan kami sebagai guru merasa kurang dengan hasil yang didapat siswa, kemudian responden R2 menyampaikan bahwa Guru tidak bisa $100 \%$ mengawasi cara belajar siswa karena tidak bisa bertatap muka secara langsung ketika melakukan pembelajaran online, sedangkan responden R3 menjawab Untuk evaluasi menurut saya pembelajaran kurang maksimal sehingga hasilpun kurang maksimal, masih banyak yang belum memahami materi IPS dengan baik.

Dan untuk pertanyaan ketiga yakni Apakah ada faktor yang menghambat dalam proses pembelajaran di tengah pandemi covid-19 mendapatkan respon jawaban yang cukup seragam, dimana responden R1 menjawab terdapat kendala dalam pembelajaran yang dilaksanakan, siswa terkadang terkendala sinyal dan paket data. Sehingga mereka untuk mengakses dan membuka file pembelajaran menjadi terganggu dan bahkan tidak bisa tepat waktu dalam mengumpulkan tugas dan hasil belajar mereka. Untuk R2 menjawab Ketika menggunakan sistem pembelajaran online, kendala yang sering dihadapi siswa yakni tentang kepemilikan gadget atau handphone serta paket data internet, masih terdapat siswa yang belum mempunyai gadget atau handphone bahkan terkendala kuota 
internet. Sedangkan responden R4 menjabarkan bahwa Faktor teknologi dan sinyal, serta tingkat pemahaman siswa berkurang.

Untuk pertanyaan terakhir yakni Bagaimana langkah anda dalam mengatasi Faktor penghambat tersebut mendapatkan respon dari responden R1 yakni dengan Memberikan hard copy materi kepada siswa baik berupa penugasan dan rangkuman materi. Kemudian responden R2 Siswa dianjurkan untuk bisa meminjam handphone kepada teman sekelas yang paling dekat dengan rumahnya. kemudian responden R3 Lebih diperbanyak dengan bentuk apresiasi dan tayangan video pendukung pembelajaran.

Berdasarkan data penelitian yang didapat melalui pengisian google form yang respondennya merupakan guru SDN Larangan Luar 03 didapat bahwa rata-rata dari Guru kelas yang bertugas mengajar pada kelas lima SDN Larangan Luar 03 Pamekasan yang melaksanakan kegiatan pembelajaran secara online adalah sebesar $67 \%$ kemudian sisanya 33\% melaksanakan secara blended learning dengan memperhatikan kondisi maupun perkembangan yang ada. kemudian $100 \%$ dari guru tersebut merencanakan pembelajaran sebelum pembelajaran Daring dilaksanakan dengan membuat perangkat pembelajaran yang menyesuaikan. Bahwasanya selama pandemi covid-19 semua guru membuat rencana pembelajaran yang berlangsung secara daring termasuk pada materi IPS keragaman suku bangsa dan budaya di Indonesia. Proses Kegiatan Belajar Mengajar pada masa pandemi dilaksanakan dengan melakukan proses pembelajaran yang memanfaatkan google form melalui whatsaap dan media lainnya yang menunjang. Namun proses KBM tersebut dirasa kurang efektif dari segi penyampaian baik dari segi materi maupun proses pencapaian tujuan pembelajaran khususnya pada materi IPS keragaman suku bangsa dan budaya di Indonesia. Untuk evaluasi belajar, para guru tersebut dilakukan secara daring, dimana guru tidak bisa 100\% mengawasi cara belajar siswa yang belajar dari rumah karena proses pembelajaran dilakukan secara daring yang mengakibatkan evaluasi pembelajaran kurang maksimal dan nantinya akan berdampak pada hasilnya yang kurang maksimal. Pada pembelajaran daring ini juga para guru menemui banyak kendala diantaranya masih terdapat siswa yang tidak memiliki gadget atau handphone yang merupakan intrumen utama serta paket data internet, selain itu pula terdapat kendala sinyal internet yang belum bisa menjangkau dengan baik sehingga mengakibatkan siswa tidak dapat mengakses dan membuka materi pembelajaran. Namun kendala tersebut bisa diatasi oleh para guru dengan cara memberikan hardcopy materi pelajaran secara langsung, rangkuman materi, penugasan dan juga lebih memperbanyak apresiasi serta motivasi untuk siswa selama belajar dari rumah.

Menurut hasil penelitian yang diperoleh, secara umum kinerja guru kelas selama pandemi Covid19 berdampak pada dunia dan Indonesia. Para 
guru khususnya guru kelas 5 SDN Larangan Luar 03 berupaya keras untuk mengolah dan merencanakan pembelajaran selama pembelajaran daring berlangsung dan selama pandemi covid-19 agar tetap terlaksana dengan baik. Namun, dalam praktiknya terdapat kendala serta kesulitan tersendiri yang dialami salah satunya oleh para guru, kendala yang umum didapat para guru atau pendidik adalah tidak dapat mengawasi, mengajarkan secara penuh dan langsung kepada siswa-siswinya. Mereka terkendala oleh jarak, waktu maupun instrument pendukung lain dalam pembelajaran daring. Namun, hal tersebut tidak menyurutkan semangat guru untuk memberikan ilmu kepada siswa. salah satu contohnya adalah dengan menggunakan atau memanfaatkan aplikasi teknologi yang cukup mudah di akses atau dipergunakan oleh peserta didik dari rumah maupun lingkungan masing-masing, seperti memanfaatkan aplikasi WhatsApp yang cukup mudah, murah dan umum digunakan oleh banyak orang. Pada sisi lain dalam melaksanakan pembelajarannya, para guru atau pendidik di SDN Larangan Luar 03 ini memiliki kendala atau faktor penghambat seperti kendala jaringan serta kebanyakan dari siswa tidak memiliki handphone yang notabennya merupakan instrument utama yang digunakan para guru maupun siswa dalam pelaksanaan pembelajaran daring selama pandemi covid-19.

\section{PENUTUP}

Kinerja guru di tengah pandemi Covid-19 di SDN Larangan Luar 03 ini bekerja keras untuk tetap menyampaikan pembelajaran kepada siswa-siswinya agar proses kegiatan belajar mengajar tetap terlaksana dengan baik khususnya pada materi etnis dan kebudayaan, meskipun terdapat beberapa faktor penghambat dalam pelaksanaan pembelajaran tersebut semisal masih banyak siswa yang tidak mempunyai gadget atau handphone, akses jaringan internet maupun kuota internet, namun para guru dapat meminimalisirkannya dengan solusi salah satunya adalah dengan memberikan hardcopy materi pembelajaran secara langsung kepada peserta didik untuk bisa dipelajari secara langsung dan mandiri dari rumah masing-masing selama pandemic covid-19. 


\section{DAFTAR PUSTAKA}

Achmad Patoni. Dinamika Pendidikan Anak. Jakarta: PT. Bina Ilmu, 2004.

Ahmad Barizi, Muhammad Idris. Menjadi Guru Unggul. Yogjakarta: Ar-Ruzz Media, 2010.

Ajat Rukajat. Pendekatan Penelitian Kuantitatif Quantitaive Research Approach. Yogyakarta: Deepublish, 2018.

Albi Anggito, Johan Setiawan. Metodologi Penelitian Kualitatif. Jawa Barat: CV Jejak, 2018.

Bastian. Akuntansi Sektor Publik Di Indonesia. Yogyakarta: BPFE, 2001.

Basuki, M. Miftahul Ulum. Pengantar Ilmu Pendidikan Islam. Ponorogo: STAIN Ponorogo Press, 2007.

Conny R. Semiawan. Metode Penelitian Kualitatif. Jakarta: Grasindo, 2017.

Didi Pianda. Kinerja Guru. Jawa Barat: CV Jejak, 2018.

Inpres, S D, Tateli Kecamatan, Mandolang Kabupaten, and Very Y Londa. "KINERJA GURU SEKOLAH DASAR DI MASA PANDEMI COVID-19 Studi Di SD Inpres Tateli Kecamatan Mandolang Kabupaten Minahasa." Jurnal Administrasi Publik 7, no. 99 (2021): 1-11.

Purwanto, Agus. "Studi Eksplorasi Dampak WFH Terhadap Kinerja Guru." Journal of Education, Psychology and Counseling 2, no. 1 (2020): 92-100.

Syafruddin Nurdin. Guru Profesional Dan Implementasi Kurikulum. Jakarta: Ciputat Press, 2003. 